CZASOPISMO INŻYNIERII LĄDOWEJ, ŚRODOWISKA I ARCHITEKTURY JOURNAL OF CIVIL ENGINEERING, ENVIRONMENT AND ARCHITECTURE

JCEEA, t. XXXIII, z. 63 (4/16), październik-grudzień 2016, s. 347-354

\author{
Artur NOWOŚWIAT ${ }^{1}$ \\ Marcelina OLECHOWSKA ${ }^{2}$ \\ Jan ŚLUSAREK ${ }^{3}$
}

\title{
PROJEKTOWANIE AKUSTYCZNE WNETRZ W ŚWIETLE NOWYCH WYMAGAŃ
}

\begin{abstract}
Streszczenie. Zgodnie z obecnie obowiązującymi normami podczas kształtowania akustycznego wnętrz określa się wartości graniczne dla czasu pogłosu i wskaźnika transmisji mowy STI. W niniejszym artykule przedstawiono odniesienie się do obowiązujących wymagań akustycznych dotyczących niektórych wnętrz, tj. wnętrz w budynkach użyteczności publicznej czy też w budynkach zamieszkania zbiorowego, oraz przedstawiono modele obliczeniowe parametrów akustycznych opisujących te wnętrza. Obowiązujące normy odnoszą się nie tylko do ograniczania hałasu pogłosowego, ale także odnoszą się do pomieszczeń przeznaczonych do prezentacji słownych. W tym zakresie odnoszą się one do zapewnienia w pomieszczeniu odpowiedniej zrozumiałości mowy. Dlatego też w niniejszej pracy przedstawiono potencjalnym projektantom pewne sugestie dotyczące kształtowania akustycznego pomieszczeń. Część badawcza pracy obejmuje analizę wpływu położenia w pomieszczeniu materiałów pochłaniających dźwięk na zmianę wartości czasu pogłosu i wskaźnika transmisji mowy STI. W tym celu zamodelowano w programie ODEON dwa pomieszczenia. Jedno z tych pomieszczeń było prostopadłościenne a drugie sześcienne i oba miały taką samą kubaturę. Następnie wykonywano symulacje czasu pogłosu i wskaźnika transmisji mowy przy różnym położeniu materiałów pochłaniających dźwięk. Przedstawiony artykuł porusza zatem problematykę kształtowania warunków akustycznych w pomieszczeniach ze względu na odbiór sygnałów słownych a przeprowadzone analizy pozwalają określić wytyczne dla projektantów zajmujących się kształtowaniem wnętrz. Wytyczne uzupełnione zostały opisem stosowanych modeli teoretycznych występujących zarówno w odpowiedniej normie jak i propozycją własną, w szczególności modelu STI(T).
\end{abstract}

Słowa kluczowe: akustyka wnętrz, czas pogłosu, Sabin, wskaźnik transmisji mowy

\footnotetext{
${ }^{1}$ Autor do korespondencji / corresponding author: Artur Nowoświat, Politechnika Śląska, Wydz. Budownictwa, ul. Akademicka 5, 44-100 Gliwice; tel. 322372878; artur.nowoswiat@ polsl.pl

2 Marcelina Olechowska, Politechnika Śląska, Wydz. Bud., ul. Akademicka 5, 44-100 Gliwice; tel. 322371567; marcelina.olechowska@polsl.pl

3 Jan Ślusarek, Politechnika Śląska, Wydz. Bud., ul. Akademicka 5, 44-100 Gliwice, tel. 322371567; jan.slusarek@polsl.pl
} 


\section{Wprowadzenie}

Wprowadzenie w 2015 roku normy [1] dotyczącej wymagań odnośnie warunków pogłosowych i zrozumiałości mowy w pomieszczeniach, spowodowało nowe spojrzenie na projektowanie pomieszczeń przeznaczonych do prezentacji słownych. W fazie projektowania pomieszczeń można zastosować symulacje komputerowe oparte na metodach promieniowych [2]. Modele teoretyczne opierają się natomiast na statystycznej teorii pola akustycznego. Zakłada się wówczas, że gęstość energii dźwiękowej w każdym punkcie wnętrza jest równa, a prawdopodobieństwo padania fali dźwiękowej jest jednakowe we wszystkich kierunkach. Prekursorem metod statystycznych był Sabin. Na bazie jego teorii powstało co najmniej kilka różnych modeli oraz teorii. Wszystkie te teorie autorzy niniejszej pracy zebrali i porównali w artykule przeglądowym [3]. W normie [1] podano również wymagania co do zrozumiałości mowy wyrażonej wskaźnikiem transmisji mowy (STI). W tym zakresie projektanci mają w zasadzie tylko do dyspozycji metody komputerowe, chociaż model teoretyczny został opracowany przez autorów niniejszego artykułu i opisany w pracy [4].

Projektowanie wnętrz ze względu na odbiór dźwięku słownego może architektom i inżynierom budownictwa sprawiać wiele kłopotów. Dlatego też powstało kilka prac $[5,6,7]$ celem których jest przedstawienie podstaw teoretycznych i praktycznych w sposób umożliwiający zrozumienie zagadnienia projektowania akustycznego. Projektując takie pomieszczenia należy uwzględnić kształt i wymiar pomieszczenia. Ponadto należy zapewnić ograniczenie hałasu w pomieszczeniu pochodzącego od wyposażenia technicznego budynku oraz innych urządzeń w budynku i poza budynkiem, a także odpowiednią izolacyjność akustyczną przegród wydzielających pomieszczenia. Podczas projektowania nie sposób również pominąć właściwego rozmieszczenia powierzchni i ustrojów o właściwościach pochłaniających, odbijających, a także rozpraszających dźwięk.

$\mathrm{Z}$ wymienionych wyżej powodów w niniejszej pracy omówione zostały metody obliczeniowe czasu pogłosu i wskaźnika transmisji mowy a także przedstawione zostały wyniki badań wpływu rozmieszczenia materiałów dźwiękochłonnych na omawiane parametry akustyczne wnętrz. Badania ograniczono do pomieszczeń prostopadłościennych. Wyniki tych badań mogą być pomocne projektantom podczas projektowania wnętrz z uwzględnieniem różnego rozmieszczenia materiałów dźwiękochłonnych.

\section{Wymagania prawne}

Wymagania prawne w budownictwie dotyczące ochrony przed hałasem zainicjowane są w Ustawie Prawo Budowlane, gdzie w artykule 5.1. możemy przeczytać iż „obiekt budowlany jako całość oraz jego poszczególne części, [...] należy, biorąc pod uwagę przewidywany okres użytkowania, projektować i bu- 
dować [...] zapewniając spełnienie podstawowych wymagań [...], dotyczących e) ochrony przed hałasem". Natomiast w Rozporządzeniu w sprawie warunków technicznych, jakim powinny odpowiadać budynki i ich usytuowanie w $\S 323.1$ wskazano że budynek powinien być zaprojektowany i wykonany w taki sposób, aby między innymi chronić go przed hałasem pogłosowym powstającym w wyniku odbić fal dźwiękowych od przegród ograniczających dane pomieszczenie. Natomiast w $§ 326$ pkt. 5 wskazano, iż „,w pomieszczeniach budynków użyteczności publicznej, których funkcja związana jest $\mathrm{z}$ odbiorem mowy lub innych pożądanych sygnałów akustycznych, należy stosować takie rozwiązania budowlane oraz dodatkowe adaptacje akustyczne, które zapewniają uzyskanie w pomieszczeniach warunków określonych odrębnymi przepisami. Adaptacje akustyczne należy wykonywać z materiałów o potwierdzonych własnościach pochłaniania dźwięku wyznaczonych zgodnie z Polską Normą określającą metodę pomiaru pochłaniania dźwięku przez elementy budowlane". Powstały zupełnie nowy dokument, odnoszący się wprost do akustyki wnętrz, jakim jest Polska Norma [1], może być traktowany jako wypełnienie zaleceń 3323 i 326 rozporządzenia. W normie tej określono wymagania dotyczące warunków pogłosowych pomieszczenia, wyrażone poprzez maksymalny czas pogłosu $T$ lub minimalną chłonność akustyczną oraz, dla pomieszczeń przeznaczonych do prezentacji słownych, zrozumiałość mowy, wyrażoną za pomocą wskaźnika transmisji mowy (STI). Norma nie dotyczy wnętrz o akustyce kwalifikowanej, takich jak sale koncertowe, czy kina, które wymagają indywidualnego podejścia.

\section{Metodologia}

Zgodnie z normą [1] w pomieszczeniach, w których zrozumiałość mowy jest jednym z warunków ich użytkowania zgodnie z przeznaczeniem, należy zapewnić odpowiedni czas pogłosu w pasmach oktawowych o środkowych częstotliwościach $125 \mathrm{~Hz}, 250 \mathrm{~Hz}, 500 \mathrm{~Hz}, 1000 \mathrm{~Hz}, 2000 \mathrm{~Hz}, 4000 \mathrm{~Hz}$ i $8000 \mathrm{~Hz}$ oraz zrozumiałość mowy wyrażoną wskaźnikiem transmisji STI. Dopuszcza się przy tym na etapie projektowania obliczenia czasu pogłosu według normy PN-EN 12354-6 [8], a wskaźnik transmisji mowy STI według PN-EN 60268-16 [9].

\subsection{Modele obliczeniowe}

Wymagania dotyczące czasu pogłosu w pomieszczeniach przeznaczonych do prezentacji słownych podane w normie [1] odnoszą się do pomieszczeń wykończonych, umeblowanych w sposób typowy dla swojej funkcji, bez ludzi.

Pogłosem w pomieszczeniu nazywamy zjawisko polegające na powolnym zanikaniu dźwięku w pomieszczeniu po wyłączeniu źródła dźwięku. Miarą pogłosu jest czas pogłosu wyrażany w sekundach i definiowany jako czas potrzebny do zmniejszenia poziomu dźwięku w pomieszczeniu o $60 \mathrm{~dB}$, po wyłączeniu źródła dźwięku. Jak już wspomniano we wstępie model obliczeniowy oparty jest 
na statystycznej teorii opisanej przez Sabine'a, a omówionej w pracy [3]. Wzór przez niego podany można zapisać w postaci:

$$
T_{S A B}=\frac{0,161 V}{S \bar{\alpha}_{S A B}} \quad[s], \quad \bar{\alpha}_{S A B}=\frac{1}{S} \sum_{i=1}^{n} \alpha_{i} S_{i}
$$

gdzie: $\quad V$ - kubatura pomieszczenia, $\mathrm{m}^{3}$,

$S$ - całkowita powierzchnia przegród ograniczających pomieszczenie, natomiast $S_{i}$ jest powierzchnią $i$-tej przegrody, $\mathrm{m}^{2}$,

$\alpha_{i}$ - współczynnik pochłaniania dźwięku $i$-tej przegrody.

Współczynnik pochłaniania dźwięku jest bezwymiarowy i przyjmuje wartości z przedziału $\langle 0,1>$ i definiuje się go jako stosunek energii fali akustycznej pochłoniętej przez materiał do energii padającej na dany materiał.

Obliczenia czasu pogłosu przeprowadzono na podstawie normy [9]. Wzór obliczeniowy przedstawiony $w$ tej normie jest uzupełnionym wzorem Sabine'a. Uzupełnienie to polega na uwzględnieniu prędkości dźwięku $c_{0} \mathrm{~W}$ pomieszczeniu i obiektów znajdujących się w pomieszczeniu. Model czasu pogłosu wówczas jest postaci:

$$
T=\frac{55,3}{c_{0}} \frac{V(1-\psi)}{A}[s]
$$

gdzie: $\psi$-frakcja obiektów, określająca stosunek objętości obiektów do $V$,

$A$ - równoważne pole powierzchni dźwiękochłonnej pomieszczenia, $\mathrm{m}^{2}$.

Można zauważyć, że normowy wzór (2) zastosowany do pomieszczenia pustego, w którym przyjęto prędkość dźwięku około $343 \mathrm{~m} / \mathrm{s}$ staje się wzorem Sabine'a (1). Pominiemy w tym miejscu opis $\psi$, gdyż analizie poddamy pomieszczenia puste. Chłonność akustyczna $A$ pomieszczenia jest sumą chłonności przegród ograniczających pomieszczenie czy też chłonności przedmiotów:

$$
A=\sum_{i=1}^{n} \alpha_{s, i} S_{i}+\sum_{j=1}^{o} A_{o b j, j}+\sum_{k=1}^{p} \alpha_{s, k} S_{k}+A_{\text {air }} \quad\left[m^{2}\right]
$$

gdzie: $\alpha_{i} S_{i}-$ chłonność akustyczna $i$-tej przegrody,

$A_{o b j, j}$ - chłonność akustyczna $j$-tego obiektu,

$\alpha_{s, k} S_{k}$ - chłonność akustyczna $k$-tego układu obiektów,

$A_{\text {air }}$ - chłonność akustyczna powietrza w pomieszczeniu.

Chłonność akustyczną powietrza w pomieszczeniach o objętości nieprzekraczającej $200 \mathrm{~m}^{3}$ można pominąć i oblicza się ją zgodnie z normą [8]. Natomiast chłonność akustyczną obiektów można obliczyć ze wzoru: 


$$
A_{o b j, j}=V_{o b j, j}^{\frac{2}{3}}\left[m^{2}\right]
$$

Wskaźnik transmisji mowy STI definiujemy jako miarę przyjmującą wartości w zakresie od 0 do 1 reprezentującą jakość transmisji mowy pod względem zrozumiałości, przez kanał transmisji mowy. Metody subiektywne szacowania zrozumiałości mowy omówiono np. w pracy [7], natomiast metody obiektywne przede wszystkim w pracy [10]. Dla celów niniejszej publikacji przytoczymy model opisany w artykule [4]. Oparty on jest na takim samym założeniu jak wzór Sabine'a, czyli równomiernym rozproszeniu pola akustycznego wewnątrz pomieszczenia. Ponadto ograniczając się do pomieszczeń o regularnym kształcie, w których żaden z wymiarów nie jest większy od pozostałych więcej niż 5 razy można stosować model zależny od czasu pogłosu $T$ :

$$
S T I=-0,2078 \ln T+0,6488
$$

\subsection{Symulacje komputerowe}

Symulacje komputerowe wykonano w programie ODEON. Obliczenia czasu pogłosu wykonywane są z wykorzystaniem metody Schrödera oraz wykorzystując dane o objętości pomieszczenia i średniej drodze swobodnej. Program rejestruje malejącą w czasie energię wirtualnych cząstek wysyłanych ze źródła w losowych kierunkach. Dla celów niniejszej pracy analizie poddano dwa puste pomieszczenia: prostopadłościenne i sześcienne. W celu uniknięcia wpływu kubatury na ostateczny wynik, przyjęto jednakową kubaturę obu analizowanych pomieszczeniach (rys 1).

W każdym z przedstawionych pomieszczeń analizowano następujące sytuacje: A - wytłumiony tylko sufit, B - wytłumiona tylko podłoga, C - wytłumiona tylko ściana przed źródłem dźwięku, D - wytłumiona tylko ściana za źródłem dźwięku.
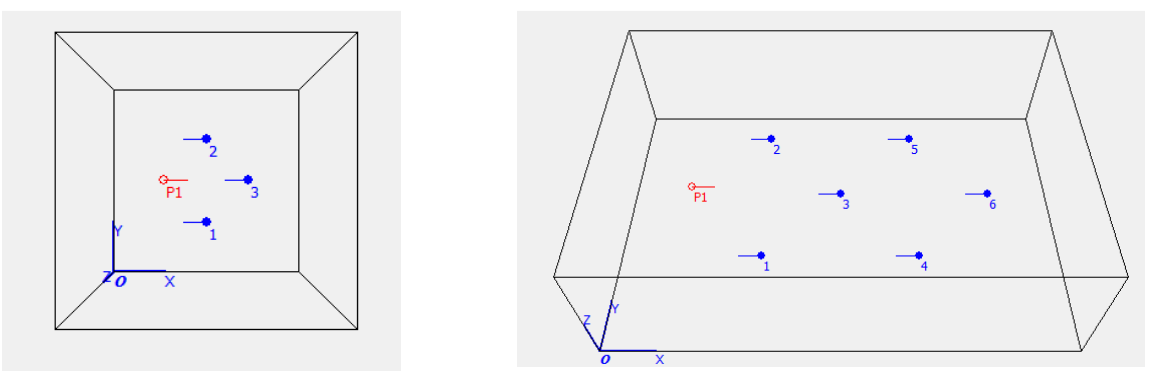

Rys. 1. Pomieszczenie sześcienne $(x, y, z)=(6,95 \mathrm{~m}, 6,95 \mathrm{~m}, 6,95 \mathrm{~m})$ (lewa strona) i prostopadłościenne $(x, y, z)=(8 \mathrm{~m}, 12 \mathrm{~m}, 3,5 \mathrm{~m})$ (prawa strona). P1-źródło dźwięku, 1-6 punkty rejestracji

Fig. 1. Cubic room $(x, y, z)=(6,95 \mathrm{~m}, 6,95 \mathrm{~m}, 6,95 \mathrm{~m})$ (left side) and rectangular $(x, y, z)=(8 \mathrm{~m}, 12 \mathrm{~m}, 3,5 \mathrm{~m})$ (right side). $\mathrm{P} 1$ - sound source, $1-6$ measurement points 
Współczynniki pochłaniania dźwięku przegród przedstawiono w tabeli 1 . Przyjęto temperaturę wewnątrz pomieszczenia $20^{\circ} \mathrm{C}$ i wilgotność $50 \%$.

Tabela 1. Współczynniki pochłaniania dźwięku

Table 1. Sound absorption coefficients

\begin{tabular}{|c|c|c|c|c|c|c|c|c|}
\hline $\begin{array}{c}\text { Częstotliwość } \\
{[\mathbf{H z}]}\end{array}$ & $\mathbf{6 3}$ & $\mathbf{1 2 5}$ & $\mathbf{2 5 0}$ & $\mathbf{5 0 0}$ & $\mathbf{1 0 0 0}$ & $\mathbf{2 0 0 0}$ & $\mathbf{4 0 0 0}$ & $\mathbf{8 0 0 0}$ \\
\hline Beton & 0,01 & 0,01 & 0,01 & 0,01 & 0,02 & 0,02 & 0,02 & 0,02 \\
\hline $\begin{array}{c}\text { Płyty dźwię- } \\
\text { kochłonne }\end{array}$ & 0,45 & 0,45 & 0,85 & 1,00 & 1,00 & 1,00 & 1,00 & 1,00 \\
\hline
\end{tabular}

\section{Analiza wyników}

Na rysunku 2 przedstawiono przebiegi czasu pogłosu w funkcji częstotliwości. Przebiegi te odzwierciedlają sytuacje A - D oraz ze wzoru (2). Analizując wykres przedstawiony na rysunku 2. można zauważyć dwa efekty. Pierwszy polega na znacznych różnicach pomiędzy obliczeniami ze wzoru (2) a symulacjami komputerowymi. Wynika to z faktu zaburzenia pola akustycznego polegającego na wytłumieniu jednej z przegród ograniczających pomieszczenie, opisanego również w [3]. Drugim efektem jest zróżnicowanie przebiegów czasu pogłosu w zależności od tego, którą powierzchnię ograniczającą wnętrze wytłumiamy.

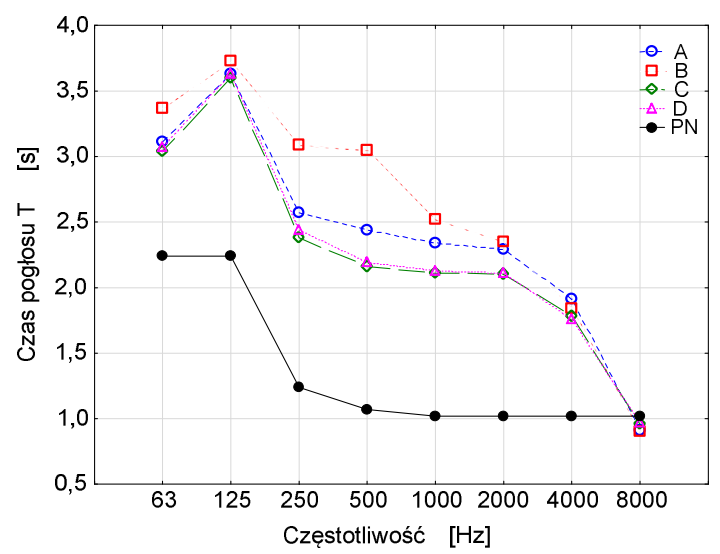

Rys. 2. Czas pogłosu w funkcji częstotliwości dla analizowanego pomieszczenia sześciennego

Fig. 2. Reverberation time as a function of frequency, cubic room

Efekt ten może być zaskakujący, gdyż analizowane pomieszczenie jest sześcienne, a zatem każda powierzchnia ograniczająca jest taka sama. Natomiast wzór normowy (2) nie uwzględnia takich różnic. Można również zauważyć, że lepiej jest wytłumiać powierzchnie przed lub za źródłem dźwięku niż po- 
wierzchnie sufitu czy podłogi. Dla pomieszczenia prostopadłościennego dochodzi jeszcze jeden efekt. Mianowicie zróżnicowanie powierzchni przegród ograniczających pomieszczenie. W takim przypadku lepiej jest wytłumić sufit czy podłogę niż ściany przed czy też za źródłem dźwięku (najczęściej powierzchni mniejsze niż sufitu i podłogi). Wyniki przedstawiono w tabeli 2.

Tabela 2. Czas pogłosu w funkcji częstotliwości dla pomieszczenia prostopadłościennego

Table 2. Reverberation time as a function of frequency, rectangular room

\begin{tabular}{|c|c|c|c|c|c|c|c|c|}
\hline $\begin{array}{c}\text { Częstotliwość } \\
{[\mathbf{H z}]}\end{array}$ & $\mathbf{6 3}$ & $\mathbf{1 2 5}$ & $\mathbf{2 5 0}$ & $\mathbf{5 0 0}$ & $\mathbf{1 0 0 0}$ & $\mathbf{2 0 0 0}$ & $\mathbf{4 0 0 0}$ & $\mathbf{8 0 0 0}$ \\
\hline A & 1,80 & 2,02 & 1,46 & 1,20 & 1,25 & 1,29 & 1,10 & 0,74 \\
\hline B & 1,73 & 1,97 & 1,25 & 1,05 & 1,07 & 1,10 & 1,03 & 0,73 \\
\hline C & 4,49 & 5,11 & 3,44 & 2,84 & 2,41 & 2,36 & 1,90 & 1,02 \\
\hline D & 4,39 & 5,00 & 3,4 & 2,64 & 2,41 & 2,34 & 1,91 & 0,99 \\
\hline
\end{tabular}

Różnice pomiędzy wartościami czasu pogłosu rozważanych przegród poziomych i pionowych wynikają zapewne ze znacznych różnic powierzchni pochłaniających. Ponadto nakłada się na to efekt zauważony przy analizie pomieszczenia sześciennego. Rozważane pomieszczenia mogą być reprezentantem na przykład klas szkolnych, którym stawia się wymagania dotyczące maksymalnych wartości czasu pogłosu i odpowiednich wartości STI. Zatem nie jest to problematyka pomijalna podczas projektowania takich pomieszczeń. Podobne efekty zauważono w pracy [11], w której autorzy zmieniali w klasach szkolnych powierzchnie pochłaniające i analizowali wyniki między innymi w programie ODEON.

\section{Wnioski}

Na podstawie wyników przedstawionych w pracy można przedstawić pewne wnioski, które mogą być pomocne podczas projektowania akustycznego wnętrz. Podstawowym wnioskiem jest fakt, iż wzór normowy (2) daje wyniki odbiegające od wyników uzyskanych w programie ODEON. Różnice te będą jeszcze większe dla pomieszczeń o bardziej zróżnicowanych powierzchniach dźwiękochłonnych, lub gdy w pomieszczeniach znajdować się będą obiekty. Ponadto dla pomieszczeń sześciennych należy przegrody za źródłem (jeśli jest to możliwe), bądź przed źródłem dźwięku pokryć materiałem wytłumiającym. Natomiast dla pomieszczeń dłuższych niż szerszych lepiej jest wytłumić sufit, lub podłogę. W celu sprecyzowania dokładnych wytycznych należałoby wykonać znacznie więcej takich analiz w kolejnych pracach.

\section{Literatura}

[1] PN-B-02151-4:2015-06. Akustyka budowlana. Ochrona przed hałasem w budynkach. Część 4: Wymagania dotyczące warunków pogłosowych i zrozumiałości mowy w pomieszczeniach. 2015. 
[2] Passero C.R., Zannin P.H.: Statistical comparison of reverberation times measured by the integrated impulse response and interrupted noise methods, computationally simulated with ODEON software, and calculated by Sabine, Eyring and Arau-Puchades' formulas, Applied Acoustics, vol.71, Issue.12, 2010, pp. 1204-1210.

[3] Nowoświat A., Olechowska M.: Investigation Studies on the Application of Reverberation Time, Archives of Acoustics, Vol. 41, No. 1, 2016, pp. 15-26.

[4] Nowoświat A., Olechowska M.: Fast estimation of speech transmission index using the reverberation time, Applied Acoustics, Vol. 102, 2016, pp. 55-61.

[5] Szudrowicz B.: Normowanie wartości czasu pogłosu w pomieszczeniach, Materiały Budowlane, 8, 2009, str. 9-12.

[6] Kłosak A.: Projektowanie akustyczne budynków, Izolacje, 5, 2012, str. 24-30.

[7] Dulak L., Nowoświat A.: Akustyka Architektoniczna - warunki pogłosowe i zrozumiałość mowy, Izolacje, 3, 2016, str. 18-23.

[8] PN-EN 12354-6 Akustyka budowlana - Określenie właściwości akustycznych budynków na podstawie właściwości elementów - Część 6: Pochłanianie dźwięku w pomieszczeniach.

[9] PN-EN 12354-16:2011 Urządzenia systemów elektroakustyczne - Część 16: Obiektywna ocena zrozumiałości mowy za pomocą wskaźnika transmisji mowy.

[10] Houtgast T., Steeneken H.J.M.: Predicting Speech Intelligibility in Rooms from Modulation Transfer Function I. General Room Acoustics, Acoustica, Vol. 46, No. 1, 1980, pp. 60-72.

[11] Bistafa S., Bradley J.: Predicting reverberation times in a simulated classroom, J. Acoust. Soc. Am., 108, 2000, pp. 1721 - 1731.

\title{
ACOUSTIC DESIGN OF THE INTERIOR IN VIEW OF MODERN REQUIREMENTS
}

\begin{abstract}
S u m m a r y
The paper presents the legally binding acoustic requirements involving certain interiors, i.e. the interiors of public utility buildings, or multi-family houses as well as the calculation models of acoustic parameters describing these interiors. The legally compulsory standards refer not only to the reduction of reverberation noise but they also concern the rooms used for verbal presentations. In this respect, they involve the problem of ensuring an appropriate understanding of speech in a room. Therefore, in the paper presented here we offer the potential designers some suggestions involving the acoustic shaping of rooms. The research part of the paper comprises the analysis involving the impact of the location of sound absorbing materials in a room on the change of reverberation time and speech transmission index STI. For that purpose, two rooms were modeled in the program ODEON. One of the rooms was cuboidshaped and the other was cube-shaped, and they both had the same cubature. Then, the simulations of reverberation time and speech transmission index for different locations of sound absorbing materials were carried out. In conclusion, the presented paper is discussing the problems involving the formation of acoustic conditions in rooms in terms of speech signal reception, and the carried out analyses enable to put forward some guidelines for designers who work on shaping the interior of rooms. The guidelines were complemented with the description of the applied theoretical models, both presented in a specific standard as well as the authors' own proposition, in particular involving the model STI(T).
\end{abstract}

Keywords: room acoustics, reverberation time, Sabine, speech transmission index

DOI:10.7862/rb.2016.279

Przestano do redakcji: $30.06 .2016 r$.

Przyjęto do druku: 20.12.2016 r. 